\section{Animal Genetics}

December 2007; VOLUME 38 (6) : Pages 601-608

http://dx.doi.org/10.1111/j.1365-2052.2007.01652.x

(c) 2007 Blackwell Publishing, Inc.

2007 International Society for Animal Genetics
Archimer, archive institutionnelle de l'Ifremer http://www.ifremer.fr/docelec/

The definitive version is available at www.blackwell-synergy.com

\title{
The effect of environmental salinity on the proteome of the sea bass (Dicentrarchus labrax L.)
}

\author{
C. L. $\mathrm{Ky}^{1,{ }^{*}}$, J. De Lorgeril ${ }^{2}$, C. Hirtz ${ }^{3}$, N. Sommerer ${ }^{4}$, M. Rossignol $^{4}$, F. Bonhomme ${ }^{2}$
}

\author{
${ }^{1}$ IFREMER, Chemin de Maguelone, 34250 Palavas-les-Flots, France \\ 2 UMR 5171 (CNRS-IFREMER-UM2), Génome, Populations, Interactions, Adaptation, 2 place Eugène Bataillon, \\ 34095 Montpellier Cdx 5, France \\ ${ }^{3}$ Université Montpellier I Laboratoire de Physiologie et Endocrinologie Oro-Faciale, 545 avenue du Pr Viala, \\ 34193 Montpellier Cdx 5, France \\ ${ }^{4}$ INRA, UR 1199, Laboratoire de Protéomique, 2 place Viala, 34060 Montpellier Cdx 1, France \\ *: Corresponding author : Ky C. L., email address : $\underline{\text { Chin.Long.Ky@ifremer.fr }}$
}

\begin{abstract}
:
The European sea bass, Dicentrarchus labrax L., tolerates a range of salinities from freshwater to hyper-saline. To study differences in protein expression, fish were reared in both freshwater and seawater. After 3-month acclimation, gill and intestine epithelia were collected and the soluble protein extracted. In all, 362 spots were differentially expressed in the gills and intestines of fishes reared in seawater compared to those from freshwater. Fifty differential protein spots were excised from a colloidal Coomassie-stained gel. Nine separate protein spots were identified unambiguously by mass spectrometry and database searching. Among the six proteins over-expressed in gill cells in seawater, five were cytoskeleton proteins and one was the aromatase cytochrome P450. In gill cells under freshwater conditions, the two over-expressed proteins identified were the prolactin receptor and the major histocompatibility complex class II $\beta$-antigen. In intestinal cells under freshwater conditions, the Iroquois homeobox protein Ziro5 was upregulated over ninefold. The expression of these proteins, their possible direct or indirect roles in the adaptation of D. labrax to salinity, and their correspondences with a previous study are discussed.
\end{abstract}

Keywords: MALDI-TOF mass spectrometry, real time PCR, salinity, sea bass, two-dimensional gel electrophoresis. 


\section{Introduction}

The common, or European, sea bass (Dicentrarchus labrax L.) is a marine teleost capable of adapting to a considerable range of environmental salinity, while maintaining an essentially constant internal osmotic pressure. It does so by means of several osmoregulatory mechanisms, mostly not only in the branchial and intestinal epithelia, but also in the cephalic kidney. It is a truly euryhaline and eurytherm species and all developmental stages can be found in different saline environments, including the open sea, estuaries, coastal lagoons and rivers. This makes it a good experimental model for studying the influence of salinity on fish physiology. Dicentrarchus labrax is able to grow and thrive in freshwater and endure a wide range of salinities, from 38 parts per 1000 to completely freshwater. Despite the potential stress to juvenile sea bass reared in freshwater, adults grow as well as those reared at seawater salinity (Chervinski 1974). This is not uncommon in euryhaline species, such as Atlantic croaker (Micropogonias undulatus), mullets (Mugil sp.) or cobia (Rachycentron canadum), which have optimum salinities much lower than the oceanic level. It is less common in the more stenohaline species, such as adult Atlantic salmon (Salmo salar) and adult gilthead seabream, which have salinity optima near the oceanic level (Boeuf \& Payan 2001).

Important advances in understanding fish molecular biology have been made through the genetic sequencing of zebrafish (Danio rerio) and pufferfish (Fugu rubripes and Tetraodon nigroviridis) (Aparicio et al. 2002; Jekosch 2004). Despite this progress, it seems necessary to study separately each fish species of economic importance when focusing on particular biological processes. Indeed, the critical nodes in the gene networks where the environment acts to influence particular responses are likely to differ from one species to the other. In particular, regulatory pathways are subject to rapid evolution (Denver et al. 2005). Large-scale gene identification has begun with an expressed sequence tag sequencing project supported by the network of excellence Marine Genomics Europe. This project has resulted in the collection of gene sequences from molluscs and fishes. In the sea bass, gene sequences from 14 different tissues were processed (more than 1200 sequences per tissue are planned).

In tilapia, osmoregulation has been studied by identifying the gene transcripts expressed during osmotic stress, based on subtractive hybridization (Fiol \& Kultz 2005). In that study, two transcription factor genes were isolated, and co-induced by an osmotic stress response (osmotic stress transcription factor 1 and transcription factor II B). Using the same approach, Boutet et al. (2006) identified genes potentially involved in the salinity response of sea bass. Four subtracted libraries were made; from gills and intestine under seawater and freshwater conditions, and have permitted the characterization of 586 partial cDNA sequences.

The aim of the present work was to study sea bass gill and intestinal epithelia proteome, changes occurring during acclimation from seawater into freshwater, and, tentatively, to identify differentially expressed proteins. These patterns could prove useful markers of freshwater transition. To this end, we combined a high resolution two-dimensional gel electrophoresis (2-DE) that separated proteins according to isoelectric point and molecular weight, with mass spectrometry (MS). Using MS, certain proteins were identified with reference to the MSDB database, which contains some proteins from the Actinopterygian class. In addition, transcript abundances of some identified proteins were evaluated by RT-PCR (real time polymerase chain reaction) to investigate their regulatory effect during osmotic acclimation. This proteomic approach supplemented the transcriptomic approach of Boutet et al. (2006).

\section{Materials and methods}

\subsection{Biological material}

Farming conditions of Dicentrarchus labrax. Sea bass (D. labrax) were produced at our experimental station and reared in recirculating seawater (salinity at 35-38 parts per thousand) at $20^{\circ} \mathrm{C}$ with a natural photoperiod. They were fed ad libitum.

Tissue collection. For proteome analysis, 100 fishes (both sexes) were sampled from both seawater and freshwater. The transfer to freshwater was carried out according to the protocol of Nebel et al. (2005). Commonly during the transfer, approximately $30 \%$ of fishes die and this was taken into 
account in deciding the number of fishes to rear. Tissues (gill and intestine) from 10 fishes, weighing $20 \pm 1.5 \mathrm{~g}$ (mean \pm standard error), were pooled. The fish were weighed and immediately killed by decapitation. The gills were dissected and rinsed in cold water corresponding to each experimental condition. The whole length of the intestine was excised and immediately linearized on an ice-cooled glass plate. Each sample was snap-frozen in liquid nitrogen and stored at $-70^{\circ} \mathrm{C}$ for further processing and protein preparation.

For transcript level analysis, a new set of fish was prepared. They were transferred as described above. At 3 and 12 months, the gills of five fishes per condition were collected by scalpel, immediately mixed on ice, homogenized (under agitation by vortex at $4^{\circ} \mathrm{C}$ for $4 \mathrm{~h}$ ) in Trizol Reagent (Gibco BRL) and stored at $-70^{\circ} \mathrm{C}$ for total RNA extraction.

\subsection{Proteome analysis}

Chemicals. Urea, phosphoric acid and acetic acid were from VWR; CHAPS, Triton $\times 100$, iodoacetamide, bromophenol blue and Comassie blue were from Sigma-Aldrich; glycerol, SDS, DTT, TGS and Tris were from Euromedex. IPG strips and buffer were from Amersham Biosciences and acrylamide from Bio-Rad.

Protein extraction. Soluble proteins were extracted according to the TCA/acetone protocol (Chevalier et al. 2004a). Briefly, $250 \mathrm{mg}$ of each tissue were ground in liquid nitrogen, and the fine powder mixed with $90 \%$ acetone $(\mathrm{v} / \mathrm{v}), 10 \%(\mathrm{v} / \mathrm{v})$ TCA solution $(100 \% \mathrm{w} / \mathrm{v})$ and $0.07 \%$ 2-mercaptoethanol $(\mathrm{v} / \mathrm{v})$. After incubation at $-20^{\circ} \mathrm{C}$ for $30 \mathrm{~min}$, the insoluble material was pelleted at $42000 \mathrm{~g}$ with a TL 100 ultracentrifuge, using a TLA 100.3 rotor (Beckman Coulter). Pellets were washed three times with pure acetone containing $0.07 \%$ 2-mercaptoethanol $(\mathrm{v} / \mathrm{v})$, air dried and solubilized in buffer containing $9 \mathrm{~m}$ urea, 4\% CHAPS (w/v), $0.05 \%$ Triton $\times 100(\mathrm{v} / \mathrm{v})$ and $65 \mathrm{~mm}$ DTT. The amount of protein was estimated using the method of Bradford (1976). All manipulations were performed at $4{ }^{\circ} \mathrm{C}$.

Two-dimensional electrophoresis. For each tissue and condition, 2-DE was performed in triplicate from the same extract using 18-cm linear $\mathrm{pH}$ 4-7 IPG strips. Five-hundred microgram protein samples were supplemented with $0.5 \%$ IPG buffer $4-7(\mathrm{v} / \mathrm{v})$ and $0.002 \%$ bromophenol blue $(\mathrm{w} / \mathrm{v})$. Strips were hydrated directly with protein solutions. Isoelectric focusing was performed using an IPG-Phor device

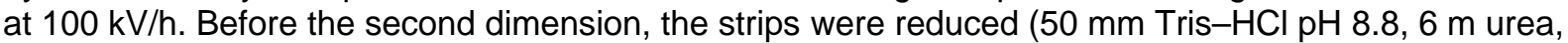
$30 \%$ glycerol (v/v), 2\% SDS (w/v), $130 \mathrm{~mm}$ DTT) and alkylated in the same buffer containing $130 \mathrm{~mm}$ iodoacetamide instead of DTT for $15 \mathrm{~min}$. Strips were then embedded using $0.6 \%(\mathrm{w} / \mathrm{v})$ low-melt agarose in running buffer containing traces of bromophenol blue on the top of a $11 \%$ acrylamide gel. SDS-PAGE was carried out using a 2-DE DALT system at $15 \mathrm{~mA}$ per gel overnight at $10^{\circ} \mathrm{C}$. Gels were stained using colloidal Coomassie blue (Chevalier et al. 2004b).

Gel image analysis. Images from stained gels were digitalized at 300 dpi with a GS 710 densitometer (Bio-Rad) and analysed using the progenesis software v2003.02 (Non-linear Dynamics). Gel triplicates from each tissue were matched to create an average gel with spots present on at least two of the three gels. Average gels corresponding to the freshwater and seawater conditions were compared. Spot intensities were quantified and normalized using the progenesis workstation software (Non-linear Dynamics). All results have been obtained using the software statistical tools based on a statistical $t$ test and allowed us to select the varying spots between the two conditions. For comparative analysis, the intensity of spots was measured by the volume (expressed as percentage of total volume of all spots on respective gels) and data were submitted to Student's $t$-test for spot selection. One-way anova was also used for spot selection and led to similar conclusions.

Specific protein spots or spots showing an increased or decreased protein expression in relation to the alternative growth condition (at least a twofold) were selected for subsequent protein identification using MALDI-TOF MS.

Protein identification by MALDI-TOF MS. Spots were picked from prepared gels (500 $\mu$ g proteins) using a spot picker robot (Perkin Elmer). Acrylamide pieces were collected in 96-well microplates with $50 \mu \mathrm{l}$ acetic acid 1\% (v/v). Pieces of gel were then washed in several steps using a Multiprobe II robot (Perkin Elmer) with water, $25 \mathrm{mM}$ ammonium carbonate and acetonitrile. Proteins were digested with trypsin $(12.5 \mu \mathrm{g} / \mathrm{ml}$ in $25 \mathrm{mM}$ ammonium carbonate). Supernatants were mixed with equal volumes of matrix solution ( $\alpha$-cyano-4-hydroxy-cinnamic acid) and spotted onto targets. Peptide mass fingerprints were acquired using a Biflex III mass spectrometer (Bruker Daltonics). Spectra were calibrated internally using trypsin peptides and annotated automatically. The mascot search engine software (Matrix Science) was used to search the MSDB database which contains proteins from the Actinopterygian class. The following parameters were used for database search: mass tolerance of 
$100 \mathrm{ppm}$, a minimum of four matched peptides, one missing cleavage allowed, and cysteine carbamidomethylation as fixed modification.

\subsection{Gene expression analysis}

RNA extraction and cDNA synthesis. Total RNAs from gills were isolated using Trizol reagent (Gibco BRL) $\left(1 \mathrm{ml} / 10^{7}\right.$ cells) and were then treated with DNase (TURBO DNase; Ambion) to remove contaminating genomic DNA and then DNase was eliminated by phenol-chloroform extraction. Firststrand cDNA was synthesized from $2 \mu \mathrm{g}$ of total gill RNA, using M-MLV Reverse Transcriptase kit, according to the manufacturer's instructions (Invitrogen), in $20 \mu \mathrm{l}$ of volume reaction.

Real-time PCR analysis. Gill CDNA of fish adapted to either freshwater or seawater for the 3- and 12month acclimation period were subjected to quantitative real-time PCR (RT-PCR) analysis, to determine whether acute changes in RNA abundance of selected genes could be affected by acclimation to salinity. Approximately, $0.5 \mu \mathrm{l}$ of each reverse transcription reaction served as a template in $10 \mu \mathrm{l}$ of RT-PCR reaction containing 1X SYBR Green master mix (Qiagen) and $0.5 \mu \mathrm{m}$ of each primer. Specific pairs of primers of prolactin receptor (referred to here as PRL-R) (PrlrF: 5'TGTCGACATATCCAGCATCG-3'; PrlrR: 5'-TCCTCATTGACCCTCTGGAC-3') and of cytochrome P450 aromatase (referred to here as P450arom) (AroF: 5'-CTCACATCCTCAGCTGGACA-3'; AroR: 5'GTGGTTTGCTGAAGCAGGA-3') were designed from sequences produced by the network of excellence Marine Genomics Europe (not yet in GenBank). In addition, specific pairs of primers were designed for two control genes: elongation factor 1- $\alpha$ (ef1a) (F: 5'-GCGGTATTGGAACTGTACCC-3', R: 5'-CTTGACGGACACGTTCTTGA-3') and $\beta$-actin (F: 5'-TTCCTCGGTATGGAGTCCTG-3', R: 5'TGGTACCTCCAGACAGCACA-3'), based on published sequences (AJ866727 and AJ537421 respectively). Each RT-PCR reaction was carried out in triplicate with an initial denaturation step of $900 \mathrm{~s}$ at $95^{\circ} \mathrm{C}$, followed by an amplification of the target cDNA ( 35 cycles of denaturation at $95^{\circ} \mathrm{C}$ for $15 \mathrm{~s}$, annealing at $55^{\circ} \mathrm{C}$ for $15 \mathrm{~s}$ and with an extension time of $15 \mathrm{~s}$ at $72{ }^{\circ} \mathrm{C}$ ) and performed with the LightCycler (Roche Molecular Biomedicals). The results presented here correspond to changes in relative expression normalized to the mean of two reference genes using the method described by Pfaffl (2001).

\subsection{Statistical analysis}

Statistical analysis of protein expression was performed using a Student's t-test, and analysis of transcript expression using Kruskal and Wallis's anova. Both analyses were carried out with statistica software v. 5.1. A P-value $<0.05$ was considered as statistically significant.

\section{Results}

\subsection{2-DE and protein expression}

The protein yield of the gills was higher than that of the intestine $(P=0.05)$ (Table 1$)$. By contrast, there was no significant difference between water conditions $(P=0.93)$ within each tissue.

The expression patterns of sea bass gill and intestinal proteomes are shown in Figs 1 \& 2 respectively. The number of spots was not significantly different for each tissue $(P=0.10)$ or for each water condition $(P=0.99)$. In gills, the average number of spots (for: pl 4-7 and molecular weight 15$150 \mathrm{kDa}$ ) was 493 in freshwater vs. 525 in saltwater. In intestine, the average number of spots was 458 in freshwater vs. 425 in saltwater. The number of differentially expressed protein spots (i.e. specific protein spots or showing at least twofold increased or decreased accumulation) was 192 (freshwater) and 170 (saltwater), irrespective of tissue. There were more differential spots with gill cells than with intestinal cells: 251 vs. 111 respectively $(P=0.018)$ whatever the water condition. In total, 362 proteins displayed differential expression, corresponding to an average of $20 \%$ of the total separated proteins, of which 50 were chosen for identification by MALDI-TOF. The choice of the 50 proteins spots was made on the basis of their: (i) good gel resolution (for efficient hand excision); (ii) normalized volume, which must reach 0.1 (threshold); and (iii) over-accumulation factor, which must reach 2 . 


\subsection{Protein identification}

Among the 50 proteins analysed by MALDI-TOF, nine were identified and their properties are summarized in Table 2 . In gills, six proteins were over-accumulated under seawater condition. In addition, the abundance of two proteins decreased under seawater condition. Only one changing protein level was detected in intestine and found to be under-accumulated under seawater condition. Among the six proteins over-expressed in gills under seawater condition, or specific of that condition, five were cytoskeleton proteins: three actins (spots 417, 148 and 529) and two $\alpha$-tubulins (spots 28 and 509), whereas the last one was identified as cytochrome P450 aromatase (P450arom) (spot 36). In gills under freshwater condition, the two identified over-accumultated proteins were: a PRL-R (spot 257 ) and a major histocompatibility complex (MHC) class II $\beta$-antigen (spot 618).

In intestinal cells under freshwater condition, the Ziro5 Iroquois homeobox protein was identified (spot 544) as upregulated more than ninefold.

\subsection{PRL-R and P450arom transcripts expression}

Among the identified proteins, two from gills, PRL-R and P450arom, were selected for gene expression analysis. Transcript abundances of PRL-R and P450arom were determined by quantitative PCR.

Figure 3a shows $P R L-R$ transcript expression levels. In freshwater, $P R L-R$ relative mean expression was over four times higher than in seawater (relative expression of 1.48 vs. $0.34, P<0.05$ ). This is consistent with the results obtained at protein level. No variation in transcript abundance was observed between different acclimation periods.

Figure $3 \mathrm{~b}$ shows P450arom expression levels. There were no significant mean differences for the two water conditions. Nevertheless, in freshwater, a significant fall in P450arom transcript abundance was observed between 3 and 12 months of acclimation (relative expression of $1.33 \pm 0.4$ vs. $0.53 \pm 0.17$, $P<0.05$ ). This was not seen in seawater where there was a large individual variation in expression at 12 months.

\section{Discussion}

\subsection{Identification of salinity-related proteins involved in cell structure, immune response and development}

Actin and tubulin accumulation in gills in seawater could be explained by morphological changes in cell structure. Indeed, in teleosts, chloride cells (ionocytes) are sites of branchial osmoregulatory activity (Philpott 1980). These cells undergo characteristic changes with osmotic challenge. Increased salinity elicits well-known changes in chloride cells, referred to as the 'hyperosmotic response'. This includes cellular proliferation and hypertrophy, an amplification of their extensive tubular network, or tubular system, an increased specific activity of the transport-associated enzyme, $\mathrm{Na}+\mathrm{K}+\mathrm{ATPase}$, and an increased electrolyte transport (Daborn et al. 2001). Actin is one of the most abundant proteins in cells. As with tubulin, it is a fundamental component of the cytoskeleton of muscular and non-muscular cells. The decreased expression of actin and tubulin accords with previous findings that show damage to the cytoskeleton following stress (Henson et al. 1997). These cytoskeletal changes are coherent with the modification of the general architecture of gill filaments. The actin cytoskeleton undergoes a structural reorganization following hypotonic exposure. At transcriptomic level, this is in accordance with the findings of Boutet et al. (2006). Indeed, actin and tubulin were also upregulated in gills of seawater-acclimated fishes.

The presence of the MHC class II $\beta$-antigen on gill epithelium exposed to freshwater indicates an immune response. Teleosts were the first vertebrates with an immune system that exerted innate and adaptive responses. The MHC produces two kinds of membrane-bound glycoprotein, class I and class $\mathrm{II}$, responsible for binding and presenting processed antigens to $\mathrm{CDB}^{+}$and $\mathrm{CD}^{+} \mathrm{T}$ lymphocytes respectively (Cuesta et al. 2006). For example, in amoebic gill disease of Atlantic salmon (Salmo salar) (caused by Neoparamoeba sp), affected tissues revealed differences in both the numbers of MHC class II cells and the level of MHC class II expression (Morrison et al. 2006). High MHC gene expression was seen in gills because of their continuous contact with a plethora of water antigens. Some authors have shown that the expression of MHC class II increases after immunization or viral/parasitic infection (Koppang et al. 1998; Sigh et al. 2004; Takano et al. 2004). Our findings with 
sea bass revealed that, in freshwater, MHC expression was twice that in seawater. This suggests that an indirect effect of rearing in freshwater is to make the fish more sensitive to exogenous antigens. The MHC class II immune system was also found to be upregulated in the gills of fishes acclimated to freshwater by Boutet et al. (2006) using a transcriptomic approach. This supports the idea of an induced immune component in freshwater acclimation.

Iroquois homeobox protein accumulated in the intestine of freshwater-acclimated fishes is involved in the development process of vertebrates. The organization of all Iroquois genes present in fish, using zebrafish (Danio rerio) and pufferfish (Fugu rubripes and Tetraodon nigroviridis) was reported by Dildrop \& Ruther 2004. The stress due to freshwater transition decreased juvenile growth (Dendrinos \& Thorpe 1985) and over-expression of Iroquois homeobox protein could explain this. The Iroquois homeobox was found only by our proteomic approach and was not identified by the transcriptomic counterpart.

\subsection{Identification of proteins implicated in the osmoregulation cascade}

Among the proteins identified, two present a potential link with osmoregulation: the PRL-R and the P450arom. These two were found only by our proteomic approach and not by transcriptomics.

Prolactin receptor is a specific cell surface receptor that binds the polypeptide hormone, PRL. PRL has separate actions on water and salt balance, growth and development, the reproductive system and immune regulation, which agrees with the ubiquitous distribution of its receptor (Hirano 1986). In fish, PRL is considered to be the major freshwater-adapting hormone, given its ability to regulate the watermineral balance. For example, in tilapia species, PRL reduces $\mathrm{Na}+$ efflux and water permeability in the gill (Dharmamba et al. 1967; Dharmamba \& Maetz 1972; Wendelaar Bonga et al. 1983; Nebel et al. 2005). In the tilapia Oreochromis niloticus, PRL-R expression was detected in the branchial chloride cells and in the intestinal mucosal layer of freshwater fish, confirming the direct control exerted by PRL on the osmoregulatory pathway (Sandra et al. 2000). In our studies, PRL-R was significantly overexpressed (threefold) at both protein and transcript levels in freshwater gill epithelium compared to that exposed to seawater. This confirms the results obtained in tilapia at the transcriptional level. Overexpression of PRL-R was not detected in the intestinal mucous cells of sea bass reared in freshwater, unlike the tilapia. This was probably due to our protein isolation methods that discarded the intestinal mucosal layer.

P450 aromatase is the enzyme complex responsible for converting androgens to estrogens in vertebrates. In the ovarian follicle, its regulation is under hormonal control, particularly PRL (Krasnow et al. 1990). In our experiment, P450arom was over-expressed in gills under seawater condition, where its direct implication in the osmoregulation process is unknown. Nevertheless, this accords with the fact that PRL-R was downregulated in gills under seawater condition. Indeed, PRL can inhibit the cyclic AMP-mediated activation of P450arom gene expression through a receptor-associated tyrosine kinase (TK) mechanism, such as PRL-R (Fortune et al. 1986; Krasnow et al. 1990). The regulation link between PRL-R and P450arom in the ovary could also occur in the gill during acclimation of D. labrax to freshwater. This is supported by the fall of P450arom transcripts seen in the later phase of acclimation to freshwater (12 months), perhaps due to the abundance of PRL-R transcripts seen in both early and later phases of acclimation ( 3 and 12 months). Moreover, large inter-individual variability of P450arom transcript abundance was seen in fish acclimated to seawater for 12 months, which does not fit with an osmoregulation function. This variability could be due to the role of the enzyme in sexual maturation, appearing only in seawater at this time of life, and thus be due to the sex differentiation of the tested fishes (Sawyer et al. 2006). In addition, we cannot exclude the possibility that modulation of P450arom transcripts did not reflect protein expression.

\section{Conclusions}

This study constitutes the first differential proteomic display approach on the response to changes in salinity by sea bass. 2-DE coupled with MALDI-TOF MS analysis on gills and intestine allowed us to identify proteins involved, directly or undirectly, in cell functions related to osmoregulation, such as cell structure modification, immune system and development responses. The study also showed the complementary nature of the proteomic approach compared to that of the transcriptome (Boutet et al. 2006). Indeed, three cases were found: (i) same molecules with both approaches, such as the 
cytoskeleton element in the same tissue and under the same water conditions; (ii) molecules found only by proteomics, such as PRL-R and aromatase cytochrome P450; and (iii) molecules found only by the transcriptomics, sush as a the well-known osmoregulated co-transportor $\mathrm{Na}^{+} \mathrm{K}^{+}$ATPase alpha 4. Identified proteins involved in the osmoregulatory cascade, and which are regulated at both transcriptomic and proteomic level, seem to be good candidate genes involved in physiological and morphological changes in the osmotic response. A further step would be to inquire into the functions of the identified proteins in the osmoregulatory process. The localization of these proteins and their transcripts from osmoregulatory organs during osmotic acclimation should be investigated. In addition, the regulatory elements of identified proteins offer an interesting route to search for polymorphisms responsible for individual fluctuations in acclimation to variations in salinity.

\section{References}

Aparicio S., Chapman J., Stupka E. et al. (2002) Whole-genome shotgun assembly and analysis of the genome of Fugu rubripes. Science 297, 1283-5.

Boeuf G. \& Payan P. (2001) How should salinity influence fish growth? Comparative Biochemistry and Physiology 130, 411-23.

Boutet I., Ky C.L. \& Bonhomme F. (2006) A transcriptomic approach of salinity response in the eurhyhaline teleost, Dicentrarchus labrax. Gene 379, 40-50.

Bradford M.A. (1976) Rapid and sensitive method for the quantitation of microgram quantities of protein utilizing the principle of protein-dye binding. Analytical Biochemistry $72,248-54$.

Chervinski J. (1974) Sea bass, Dicentrarchus labrax, Linne (Pisces, Serranidae) a police-fish in freshwater ponds and its adaptability to various saline conditions. Bamidgesh 26, 110-3.

Chevalier F., Martin O., Rofidal V., Devauchelle A.-D. \& Rossignol M. (2004a) Proteomic investigation of natural variation between Arabidopsis ecotypes. Proteomics 4, 1372-81.

Chevalier F., Rofidal V., Vanova P., Bergoin A. \& Rossignol M. (2004b) Proteomic capacity of recent fluorescent dyes for protein staining. Phytochemistry 65, 1499-506.

Cuesta A., Angeles Esteban M. \& Meseguer J. (2006) Cloning, distribution and up-regulation of the teleost fish MHC class II alpha suggests a role for granulocytes as antigen-presenting cells. Molecular Immunology 43, 1275-85.

Daborn K., Cozzi R.R. \& Marshall W.S. (2001) Dynamics of pavement cell-chloride cell interactions during abrupt salinity change in Fundulus heteroclitus. The Journal of Experimental Biology 204, 1889-99.

Dendrinos P. \& Thorpe J.P. (1985) Effects of reduced salinity on growth and body composition in the European sea bass Dicentrarchus labrax. Aquaculture 49, 333-58.

Denver D.R., Morris K., Streelman J.T., Kim S.K., Lynch M. \& Thomas W.K. (2005) The transcriptional consequences of mutation and natural selection in Caenorhabditis elegans. Nature Genetics 37, 5448.

Dharmamba M. \& Maetz J. (1972) Effects of hypophysectomy and prolactin on the sodium balance of Tilapia mossambica in fresh water. General and Comparative Endocrinology 19, 175-83.

Dharmamba M., Handin R.I., Nandi J. \& Bern H.A. (1967) Effect of prolactin on freshwater survival and on plasma osmotic pressure of hypophysectomized Tilapia mossambica. General and Comparative Endocrinology 9, 295-303.

Dildrop R. \& Ruther U. (2004) Organization of Iroquois genes in fish. Development Genes and Evolution 214, 267-76. 
Fiol D.F. \& Kultz D. (2005) Rapid hyperosmotic coinduction of two tilapia (Oreochromis mossambicus) transcription factors in gill cells. Proceedings of the National Academy of Sciences of the United States of America 102, 927-32.

Fortune J.E., Wissler R.N. \& Vincent S.E. (1986) Prolactin modulates steroidogenesis by rat granulosa cells: II. Effects on estradiol. Biology of Reproduction 35, 92.

Henson J.H., Roesener C.D., Gaetano C.J., Mendola R.J., Forrest J.N. Jr, Holy J. \& Kleinzeller A. (1997) Confocal microscopic observation of cytoskeletal reorganizations in cultured shark rectal gland cells following treatment with hypotonic shock and high external $\mathrm{K}+$. The Journal of Experimental Zoology 279, 415-24.

Hirano T. (1986) The spectrum of prolactin action in teleosts. In: Comparative Endocrinology: Developments and Directions (Ed. by C. Ralph), pp. 53-74.

Jekosch K. (2004) The zebrafish genome project: sequence analysis and annotation. Methods in Cell Biology 77, 225-39.

Koppang E.O., Lundin M., Press C.McL., Rønningen K. \& Lie Ø. (1998) Differing levels of MHC class II $\beta$ chain expression in a range of tissues from vaccinated and non-vaccinated Atlantic salmon (Salmo salar L.). Fish \& Shellfish Immunology 8, 183-96.

Krasnow J.S., Hickey G.J. \& Richards J.S. (1990) Regulation of aromatase mRNA and estradiol biosynthesis in rat ovarian granulosa and luteal cells by prolactin. Molecular Endocrinology 4, 13.

Morrison R.N., Koppang E.O., Hordvik I. \& Nowak B.F. (2006) MHC class II+ cells in the gills of Atlantic salmon (Salmo salar L.) affected by amoebic gill disease. Veterinary Immunology and Immunopathology 109, 297-303.

Nebel C., Romestand B., Nègre-Sadargues G., Grousset E., Ajoulat F., Bacal J., Bonhomme F. \& Charmantier G. (2005) Differential freshwater adaptation in juvenile sea-bass Dicentrarchus labrax: involvement of gills and urinary system. The Journal of Experimental Biology 208, 3859-71.

Pfaffl M.W. (2001) A new mathematical model for relative quantification in real-time RT-PCR. Nucleic Acids Research 29, 2002-7.

Philpott C.W. (1980) Tubular system membranes of teleost chloride cells: osmotic response and transport sites. The American Journal of Physiology 238, 171-84.

Sandra O., Le Rouzic P., Cauty C., Edery M. \& Prunet P. (2000) Expression of the prolactin receptor $($ tiPRL-R) gene in tilapia Oreochromis niloticus: tissue distribution and cellular localization in osmoregulatory organs. Journal of Molecular Endocrinology 24, 215-24.

Sawyer S.J., Gerstner K.A. \& Callard G.V. (2006) Real-time PCR analysis of cytochrome P450 aromatase expression in zebrafish: gene specific tissue distribution, sex differences, developmental programming, and estrogen regulation. General and Comparative Endocrinology 147, 108-17.

Sigh J., Lindestrøm T. \& Buchmann K. (2004) The parasitic ciliate Ichthyophthirius multifiliis induces expression of immune relevant genes in rainbow trout, Oncorhynchus mykiss (Walbaum). Journal of Fish Diseases 27, 409-17.

Takano T., Iwahori A., Hirono I. \& Aoki T. (2004) Development of a DNA vaccine against hirame rhabdovirus and analysis of the expression of immune-related genes after vaccination. Fish \& Shellfish Immunology 17, 367-74.

Wendelaar Bonga S.E., Lowick C.J. \& Van der Meij J.C.A. (1983) Effects of external Mg2+ and Ca2+ on branchial osmotic water permeability and prolactin secretion in the teleost fish Sarotherodon mossambicus. General and Comparative Endocrinology 52, 222-31. 
Table 1 Soluble protein yield (expressed in $\mathrm{mg}$ of protein per $\mathrm{mg}$ of fresh tissue) in gill and intestine from fishes kept in freshwater and seawater.

\begin{tabular}{|c|c|c|c|}
\hline Gill & & \multicolumn{2}{|l|}{ Intestine } \\
\hline Freshwater & Seawater & Freshwater & Seawater \\
\hline 29.2 & 34.4 & 17.2 & 14.5 \\
\hline
\end{tabular}

Table 2 Protein spots isolated from 2-D gels identified by MALDI-TOF mass spectrometry in combination with searches in the mascot database restrained to Actinopterygii.

\begin{tabular}{|l|l|l|l|l|l|l|l|l|}
\hline Protein name (species) & $\begin{array}{l}\text { Accession (Swiss } \\
\text { prot) }\end{array}$ & $\begin{array}{l}\text { Protein } \\
\text { function }\end{array}$ & $\begin{array}{l}\text { Spot } \\
\text { no. }\end{array}$ & $\begin{array}{l}\text { Expression } \\
\text { factor (SW/FW) }\end{array}$ & Tissue & $\begin{array}{l}\text { mascot } \\
\text { score }\end{array}$ & $\begin{array}{l}\text { Sequence } \\
\text { coverage }\end{array}$ \\
\hline Tubulin $\alpha$ (Brachydanio rerio) & O42271_BRARE & Cytoskeleton & 28 & SW-specific & Gills & 121 & 26 \\
(theorlexp)
\end{tabular}




\section{Figures}

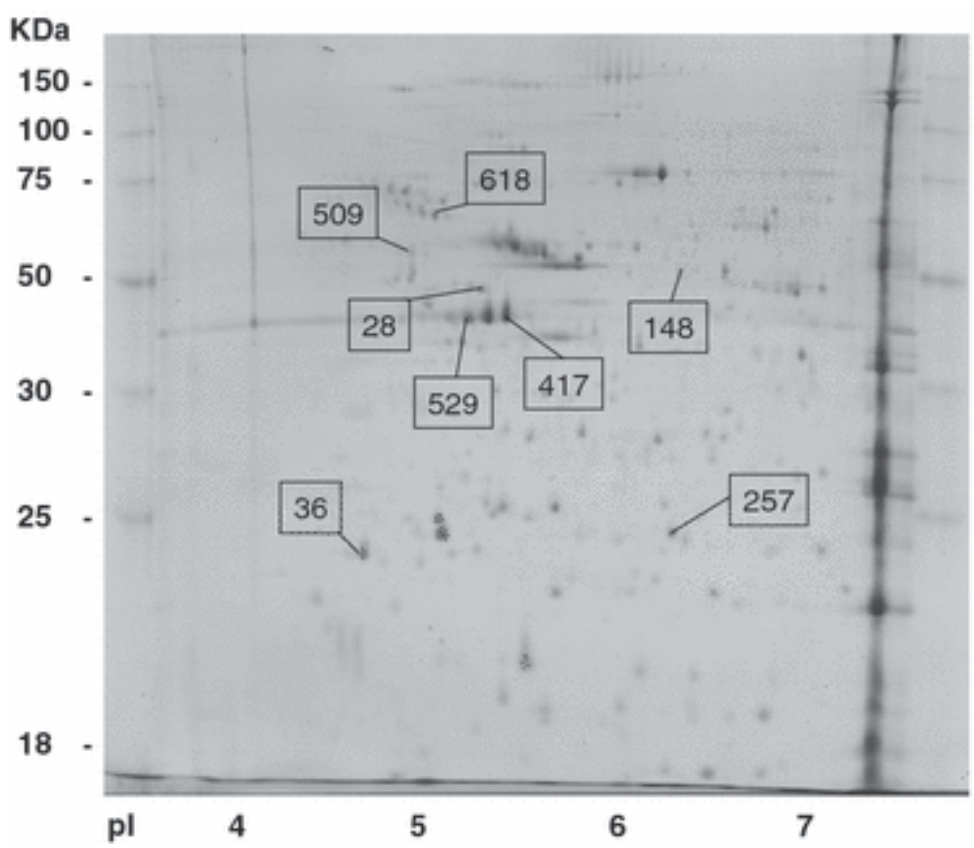

Figure 1 Average colloidal Coomassie blue gel staining obtained from the gills of sea bass showing differentially accumulated proteins identified with MALDI-TOF mass spectrometry. Five-hundred micrograms of protein were resolved using pH 4-7 NL IPG and 11\% SDS-PAGE.

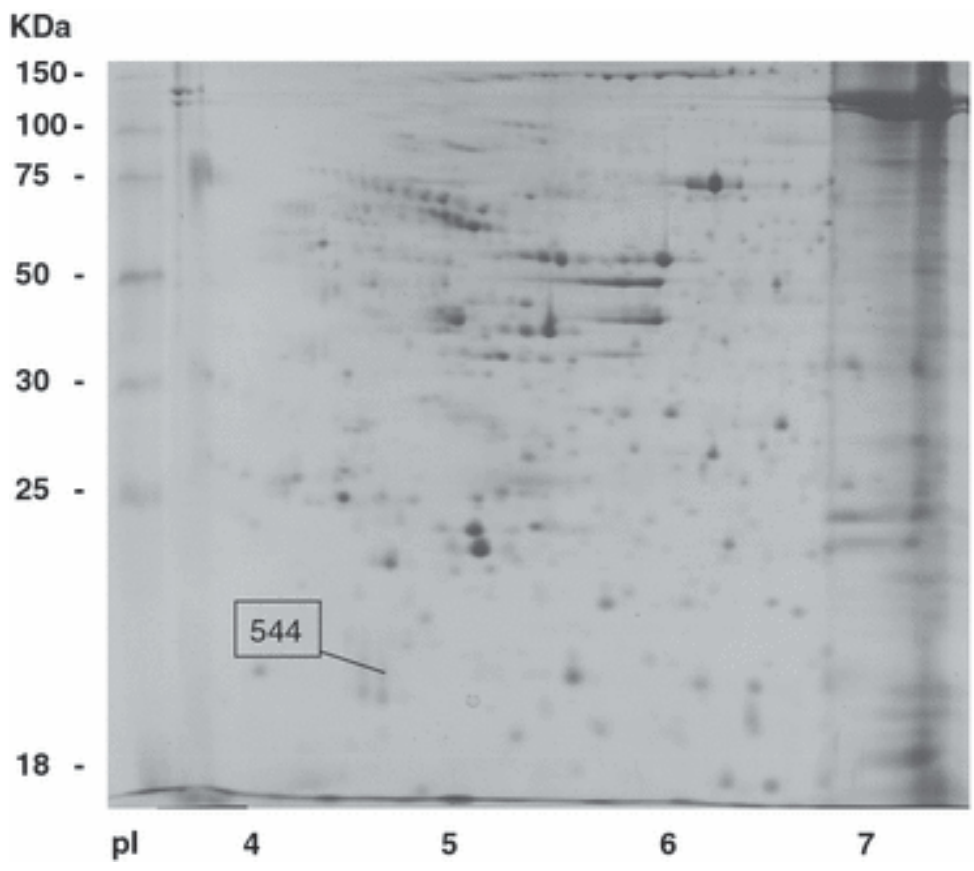

Figure 2 Average colloidal Coomassie blue gel staining obtained from the intestine of sea bass showing differentially accumulated proteins identified with MALDI-TOF mass spectrometry. Fivehundred micrograms of protein were resolved using $\mathrm{pH}$ 4-7 NL IPG and 11\% SDS-PAGE. 

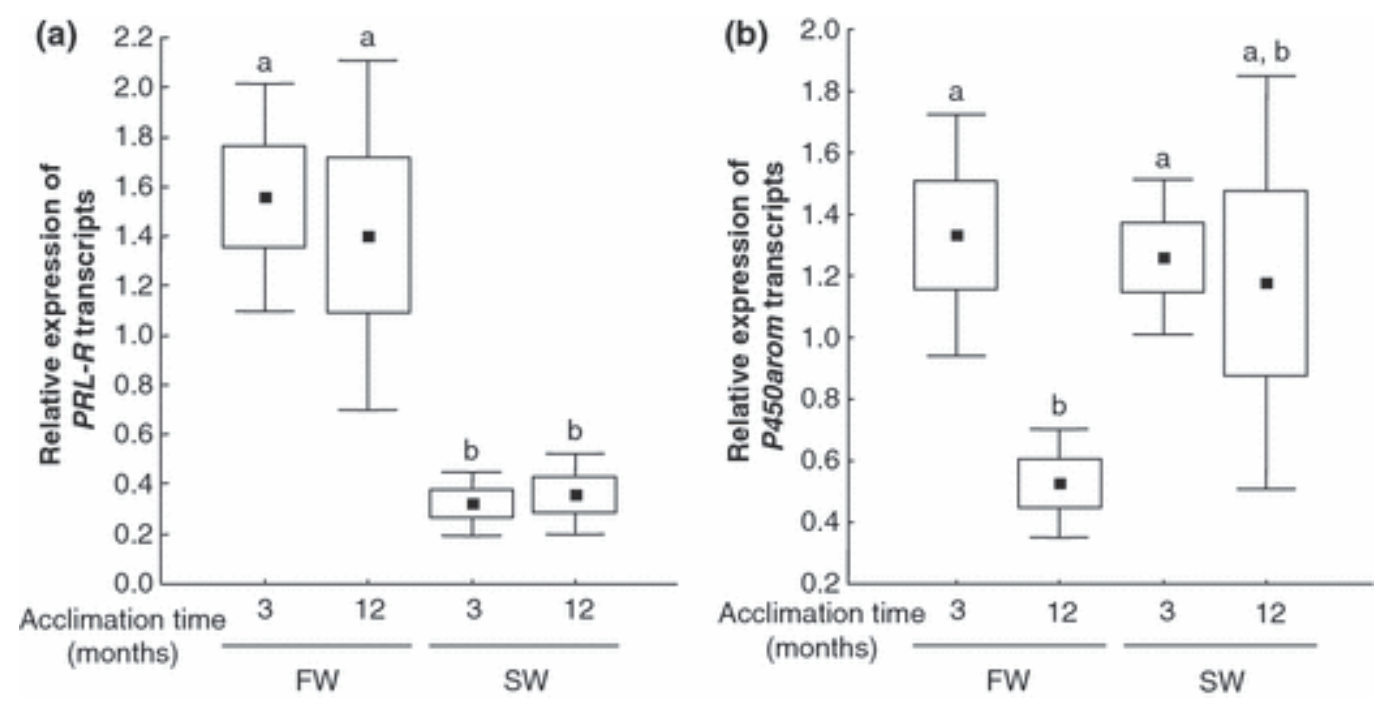

Figure 3 Real-time PCR analysis of prolactin receptor transcripts (PRL-R) (a) and aromatase cytochrome P450 transcripts (P450arom) (b) from sea bass gills in freshwater (FW) and seawater (SW) during 3- and 12-month acclimation periods. Results are expressed as mean values (black square) $\pm \mathrm{SE}$ (box), $\pm S D V$ (bar) from five fish per condtion. Relative expression levels were normalized with the mean of two control genes (elongation factor $1 \alpha$ and actin) and values were calculated with reference to the first individual of the first condition (SW -3 months), according the $2^{-\Delta \Delta C t}$ method (Pfaffl 2001). Results of the Kruskal and Wallis's anova test are indicated with letters. 